\title{
Hox genes and morphological identity: axial versus lateral patterning in the
} \section{vertebrate mesoderm}

\author{
Julie L. Nowicki ${ }^{1}$ and Ann C. Burke ${ }^{2, *}$ \\ ${ }^{1}$ University of North Carolina, Department of Biology, Chapel Hill, NC 27599, USA \\ 2Wesleyan University, Biology Department, Middletown, CT 06459, USA \\ *Author for correspondence (e-mail: acburke@wesleyan.edu)
}

Accepted 23 June; published on WWW 7 September 2000

\section{SUMMARY}

The successful organization of the vertebrate body requires that local information in the embryo be translated into a functional, global pattern. Somite cells form the bulk of the musculoskeletal system. Heterotopic transplants of segmental plate along the axis from quail to chick were performed to test the correlation between autonomous morphological patterning and Hox gene expression in somite subpopulations. The data presented strengthen the correlation of Hox gene expression with axial specification and focus on the significance of $H o x$ genes in specific derivatives of the somites. We have defined two anatomical compartments of the body based on the embryonic origin of the cells making up contributing structures: the dorsal compartment, formed from purely somitic cell populations; and the ventral compartment comprising cells from somites and lateral plate. The boundary between these anatomical compartments is termed the somitic frontier. Somitic tissue transplanted between axial levels retains both original Hox expression and morphological identity in the dorsal compartment. In contrast, migrating lateral somitic cells crossing the somitic frontier do not maintain donor Hox expression but apparently adopt the Hox expression of the lateral plate and participate in the morphology appropriate to the host level. Dorsal and ventral compartments, as defined here, have relevance for experimental manipulations that influence somite cell behavior. The correlation of $H o x$ expression profiles and patterning behavior of cells in these two compartments supports the hypothesis of independent Hox codes in paraxial and lateral plate mesoderm.

Key words: Hox genes, Somites, Lateral plate, Global patterning, AP axis, Chick-quail

\section{INTRODUCTION}

The musculoskeletal system of vertebrates arises from two populations of embryonic mesoderm. The axial skeleton, with the exception of the skull, arises from somites, as do virtually all of the striated muscles of the body. The appendicular skeleton and the connective tissue of the limbs and body wall arise from the somatic layer of the lateral plate. The Hox family of transcription factors is known to influence both the development and the evolution of this morphology (Krumlauf, 1992; Gaunt, 1994; Burke et al., 1995).

\section{Vertebrate morphology, mesodermal derivatives and anatomical compartments}

The axial formula of an animal is the number of segments included in each anatomical region (Fig. 1A). Despite transpositional variation in the axial formulae of different species, the basic body plan of vertebrates is quite conservative. In tetrapods, the forelimb always lies at the cervical to thoracic transition, and the hindlimb always lies at the lumbosacral transition, regardless of variation in the number of segments in these regions. Because the limb buds form in lateral plate tissue, the lateral plate mesoderm must align with the somites to allow proper arrangement of the appendicular skeleton with regard to the axial skeleton.

The somites are serially homologous embryonic structures. When they first form, each somite along the anterior-posterior (AP) axis is morphologically identical to every other somite (Fig. 1B), and eventually gives rise to the same suite of cell types (muscle, bone and dermis). There are many local factors that participate in the patterning of all somites and determine the ultimate differentiation state of somitic cells. The overall global patterning in which each somite participates, however, is dramatically different depending on its AP position. Global pattern requires the coordination of somite fate in the context of lateral tissue as well as with regard to all the other somites along the axis (Burke, 2000).

In the dorsal to ventral dimension, the body is traditionally divided into epaxial and hypaxial regions, respectively (Romer, 1977). The basis for this distinction is the innervation of the muscle groups: epaxial muscles are served by the dorsal ramus of the spinal nerve, and hypaxial muscles by the ventral ramus. In this paper we define dorsal and ventral compartments based on the embryonic origin of the cells included. Tissues in the dorsal compartment are made up exclusively from somitic cells. Structures in the ventral compartment are composed of 
cells from both somites and lateral plate mesoderm. The dorsal and ventral compartments are usually, but not always, consistent with the epaxial and hypaxial regions. For instance, the intercostal muscles, innervated by ventral ramus and therefore hypaxial, lie in the dorsal compartment, as does the longus colli ventralis. We propose that the control of global patterning in dorsal and ventral compartments is partially independent, and suggest that the recognition of these compartments is of critical importance in the interpretation of experimental perturbations.

The dorsal compartment comprises the vertebra and ribs; the epaxial and paravertebral musculature; the connective tissues in which those tissues form, and the dorsal dermis. These tissues can be described as autochthonous (Christ et al., 1983), in that they undergo growth and differentiation essentially in situ, without actively migrating or mixing with other mesodermal populations. The ventrolateral edge of this dorsal cell population we refer to as the somitic frontier. The somitic frontier marks the transition from a fully somitic cell population to a mixed population of lateral plate and migrating somitic myoblasts (Fig. 1C). The position of the frontier relative to the dorsoventral plane is not constant but varies along the AP axis (J. L. N. and A. C. B., unpublished).

The ventral compartment comprises the limbs, ventrolateral body wall and the bulk of the hypaxial muscles. These tissues are composites of lateral plate-derived connective tissues and the migratory population of the myotome. Cells from the ventrolateral dermomyotome migrate across the somitic frontier, forming a population of axially derived cells that closely interact with lateral mesoderm (Fig. 1C). In this ventrolateral population, the AP level of the somite is manifest in different structures of the body wall, limb position and the bulk of hypaxial muscles.

\section{Migratory modes and molecular determinants of somite behavior}

The overall behavior and ultimate pattern of somite cells as they enter the ventral compartment are quite different in the neck, limb and flank of the developing embryo. Thus, somite cells in both dorsal and ventral compartments either contain or acquire information that will ensure correct global body pattern. Experimental manipulations demonstrate specific roles for a growing number of genes in the specification and behavior of somite cells, including migratory behavior of myoblasts at different axial levels. Three distinct types of expansion across the somitic frontier have been described and many of the molecular actors in this behavior are now partially understood (reviewed by Dietrich, 1999). Some genes have differential expression patterns along the axis. (e.g., scatter factor, Théry et al., 1995; Lbxl, Dietrich et al., 1998; Dietrich, 1999) consistent with a role in influencing migratory behavior. However, it is unclear how this information has been directed to discrete axial locations, and the source of axial differences are clearly upstream of these factors. The search for a source of global information leads back to the Hox genes and the mechanistic role they play in setting up downstream, localized responses.

Hox genes are the most attractive candidates for the specification of global axial identity of many tissue types. These transcription factors, highly conserved throughout
Metazoan evolution, are involved in setting up positional identities of segments along the AP axis (McGinnis and Krumlauf, 1992). They possess a remarkable parallel between genotype and phenotype, termed colinearity, which provides a mechanism for translating local information into global pattern (Duboule, 1994; Lewis, 1978; Duboule and Dollé, 1989; Graham et al., 1989).

Each Hox gene has a specific anterior boundary of expression within a variety of tissues. These boundaries of expression, however, do not necessarily align in each embryonic tissue type. For instance, the neural boundary for one gene is generally more anterior than is the boundary for that gene in the paraxial mesoderm. There are also boundaries in lateral plate mesoderm that are often offset from the boundary of the same gene in the somitic mesoderm (Cohn et al., 1997; Oberg and Eichele, 1999).

Loss-of-function mutations and overexpression studies in mice with many of the Hox genes lead to 'homeotic' changes in vertebral axial identities (reviewed in McGinnis and Krumlauf, 1992; Crawford, 1995; Charité et al., 1994). Hox genes may also be responsible for setting up positional information in the lateral plate mesoderm, allowing for proper limb positioning along the axis (Rancourt, 1995; Cohn et al., 1997). Comparative studies also provide strong support for the involvement of Hox genes in patterning the vertebrate axial structures (Gaunt, 1994; Burke et al., 1995). The boundaries of Hox expression in the paraxial mesoderm map to distinct morphological boundaries along the axis in vertebrates, regardless of the number of body segments in each morphological region in different species.

Several classical studies have assessed the morphological plasticity of somite mesoderm by heterotopic transplants and described a strong level of autonomous patterning in somite tissues with regard to their global position (Kieny et al., 1972; Murakami and Nakamura, 1991). More-recent experiments have demonstrated autonomy of Hox expression in mesoderm as well. Somites transposed to certain levels along the axis can influence the Hox expression in adjacent neural tissue (Itasaki et al., 1996), and level specific Hox c8 protein expression is maintained in somites transplanted between thoracic and brachial levels (Ensini et al., 1998). Earlier, somite transplants in transgenic mice suggested that lacZ expression under control of a Hox promoter could be maintained at heterotopic axial levels (Beddington et al., 1992). Occipital somites transplanted to the cervical region do not turn on neck-specific Hox genes (Kant and Goldstein, 1999).

This paper describes the classical surgical perturbations we have used to challenge the global identity of somitic tissue and test the role of Hox genes in patterning the somitic derivatives. We explore determination of AP positional information in both the dorsal and the ventral anatomical compartments. We suggest that viewing the body wall based on cell origin (somite versus lateral plate) reveals a fundamental distinction that can explain patterning along the axis and provides a new perspective for interpreting experimental results. Our data strengthen the correlation of positional identity with Hox gene expression and further define the significance of Hox genes in patterning derivatives of the somitic mesoderm. 


\section{MATERIALS AND METHODS}

\section{Surgeries}

Fertilized chick (White Leghorn) and Japanese quail eggs were obtained from SPAFAS (Norwich, CT, USA) or Truslow Farms (Chestertown, MD, USA) and incubated at $37^{\circ} \mathrm{C}$. Embryos were staged according to Hamburger and Hamilton (H\&H) (1951). Heterotopic anterior to posterior (A to $\mathrm{P}$ ), and posterior to anterior ( $\mathrm{P}$ to A) transplants of segmental plate (SP) were performed by staggering the stages of donor and host, as summarized in Fig. 2.

Donor embryos were removed from eggs and membranes and pinned out dorsal side up in Sylgard (Corning) dishes in 0.15\% trypsin in calcium- and magnesium-free Tyrode's. Ectoderm was peeled from the SP with a tungsten needle. Anterior-most SP equivalent to approximately four somites was removed. Host embryos were prepared in ovo. At the graft site, a small amount of trypsin was applied, ectoderm was peeled back and four somites worth of SP were removed. The graft was inserted in proper orientation. Eggs were sealed and incubated for 1-8 days. Orthotopic controls were performed to ensure normal morphology and Hox expression after surgical manipulation. Control host embryos with no donor tissue added were fixed immediately after surgery and sectioned to confirm the complete removal of SP tissue.

\section{Skeletal staining}

Embryos were fixed on post-operative day $7-8$ in $10 \%$ formalin overnight, rinsed in PBS, dehydrated into ethanol and stained for 1-3 days in $0.1 \%$ Alcian Blue GX (Sigma). After clearing in a graded series of $0.5 \% \mathrm{KOH}$ and glycerol, specimens were pinned out dorsal side up and photographed with a Nikon SMZ-U stereo microscope with Kodak Elite film.

\section{Immunohistochemistry}

Muscle pattern was visualized using an antibody to sarcomere myosin (adapted from Kardon, 1998). Embryos were fixed on post-operative day 7-8 in $4 \%$ paraformaldehyde (PFA), washed in PBS and eviscerated. Briefly, embryos were bleached overnight in Dent's bleach, postfixed in Dent's fix (1:4 DMSO:MeOH), washed in PBS and incubated overnight at $4^{\circ} \mathrm{C}$ in MF20 antibody (DSHB supernatant, 1:200). Label was detected using HRP-conjugated secondary antibody (goat anti-mouse, Jackson labs 1:200), and visualized with $0.5 \mathrm{mg} / \mathrm{ml}$ DAB in $0.1 \% \mathrm{H}_{2} \mathrm{O}_{2}$.

In quail-chick chimeras, the quail-specific antibody QCPN (DSHB, 1:10) was used to detect quail cells in the chick environment (Schneider, 1999). Embryos were fixed 2-6 days post operatively in $4 \%$ PFA, embedded in paraffin and sectioned at $10 \mu \mathrm{m}$ on a Zeiss Microm. Sections were dewaxed in Hemo-De, postfixed in Serra's fix, rehydrated and incubated in primary antibody overnight at $4^{\circ} \mathrm{C}$. Positive cells were detected using HRP-conjugated secondary antibody as above. Slides were mounted with Glycergel (DAKO) and photographed on a Nikon Optiphot. Pax7 labeling (DSHB, 1:10) was performed as for QCPN.

\section{In situ hybridization}

Chicken Hox c6, Hox $c 9$ and Hox $c 8$ were cloned in the Tabin lab, as reported in Nelson et al., 1996. Hox a6 was obtained from A. Kuroiwa in Nagoya, Japan. Pax3 and MyoD were obtained from M. BronnerFraser and cloned by Stark et al. (1997) and Lin et al. (1989) respectively. pBluescript DNAs with the above inserts were linearized and used as templates to generate RNA probes. Probes were transcribed with T3 or T7 RNA polymerase (Boehringer) with digoxigenin UTP (Boehringer), precipitated with $4 \mathrm{M} \mathrm{LiCl}$, resuspended in TE, $\mathrm{pH} 8$ and stored at $-20^{\circ} \mathrm{C}$. Embryos were sacrificed at 2-3 days post op, fixed in 4\% PFA and rinsed in PBS for whole-mount in situ hybridization as in Burke and Nelson (1996). For sectioned in situs, embryos were embedded in paraffin after fixation, $8 \mu \mathrm{m}$ sections were cut and in situ hybridization was performed as in Bronner-Fraser (1996).

\section{RESULTS}

We performed heterotopic, heterospecific SP transplants. Fig. 2 shows a schematic summary of the axial levels of the surgeries performed, and Table 1 summarizes the results. A percentage of surgeries result in graft rejection and embryos that are unaffected. First, we describe the morphological effects on bone and muscle. Next, we describe expression of several Hox genes in embryos with SP transplants, as detected by both whole-mount and sectioned in situ hybridizations. The terms dorsal and ventral compartments, described in the introduction, are used throughout the results to interpret the data presented.

\section{Morphological results of segmental plate transplants}

Muscle terminology follows that of Nickel et al. (1977). Muscles chosen for examination were based on previous mapping studies showing the specific somitic origins of each muscle group. Dorsal paravertebral muscles arise from all axial levels of interest here, and were examined in all transplants (somites (So) 6-29). Other specific muscles were examined in each axial region, specifically; at the cervical level (So 6-18) - longus colli ventralis; at the brachial level (So 12-20) - pectoral and wing muscles; at trunk level (So 19-26) - intercostal muscles; and at lower thoracic levels (So 26-29) - abdominal musculature (Chevallier et al., 1977; Chevallier, 1977, 1978; Christ et al., 1983; reviewed by Gumpel-Pinot, 1984).

\section{A-to-P transplants}

A total of 22 embryos with transplants of SP from the level of So 9-14 (cervical) to the level of So 19-24 (thoracic) (see Table 1) were allowed to develop for 7 days. Sixteen embryos were cleared and stained to visualize the skeleton, and seven were stained with MF20 antibody to visualize skeletal muscle. Common defects in the skeleton and musculature are limited to the operated side of the embryo at the level of the graft site and are typified by the specimens in Fig. 3 .

Skeletal abnormalities in this group of transplants include the absence of several thoracic ribs, vertebral anomalies and scapular defects. After dissection of this embryo, the chimeric nature of the vertebrae at the thoracic level can be easily seen (Fig. 3B,C). Operated side vertebrae and ribs maintain cervical morphology at the thoracic level, including vertebral morphology and lack of thoracic rib.

Table 1. Summary of segmental plate transplant results

\section{(A) Type of surgery}

\begin{tabular}{lcc} 
& A-to-P & P-to-A \\
\hline Donor somite level & $9-14$ & $19-26$ \\
Host somite level & $19-24$ & $9-14$
\end{tabular}

\section{(B) Analysis}

\begin{tabular}{lcccc} 
& $\begin{array}{c}\text { No. } \\
\text { examined }\end{array}$ & $\begin{array}{c}\text { No. } \\
\text { affected }\end{array}$ & $\begin{array}{c}\text { No. } \\
\text { examined }\end{array}$ & $\begin{array}{c}\text { No. } \\
\text { affected }\end{array}$ \\
\hline $\begin{array}{l}\text { Skeletal } \\
\text { Muscle }\end{array}$ & 16 & 11 & 18 & 14 \\
$\begin{array}{l}\text { Hox a6 and Hox c6 } \\
\quad \text { expression }\end{array}$ & 17 & 7 & 2 & 2 \\
$\begin{array}{l}\text { Hox } 8 \text { and Hox c9 } \\
\quad \text { expression }\end{array}$ & 10 & 4 & 4 & 6 \\
\hline
\end{tabular}



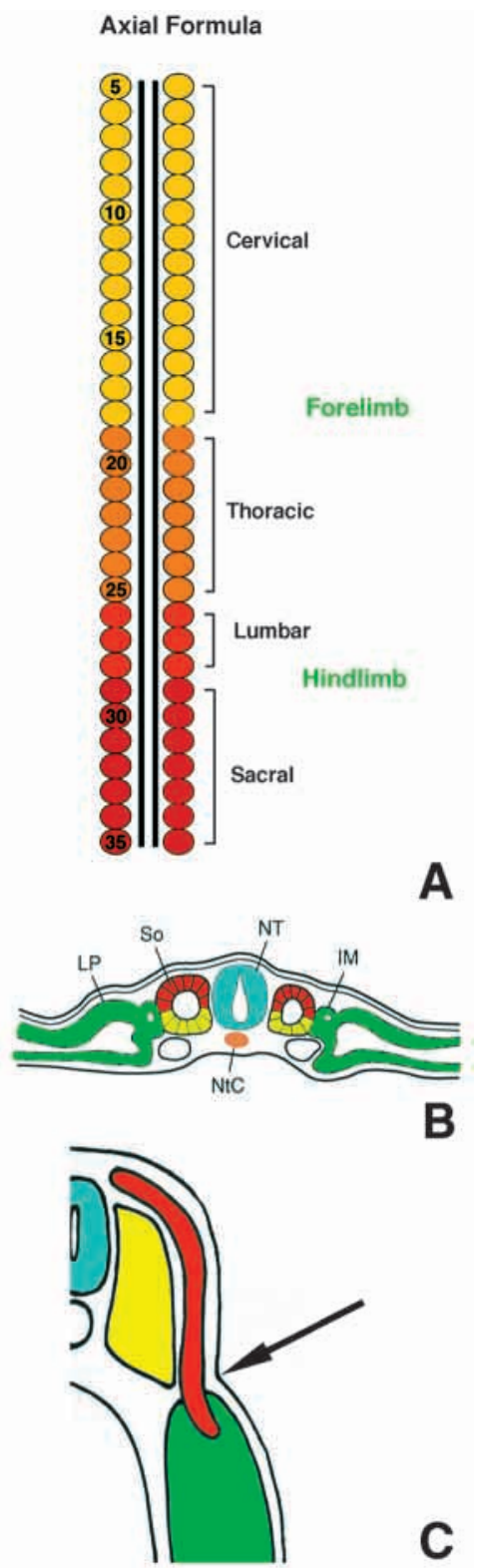

C

Fig. 1. (A) Schematic axial formula of a chicken. Note conserved placement of forelimb and hindlimb. (B) Cross section of chick embryo through the level of a recently formed somite, showing somitic mesoderm (So), lateral plate mesoderm (LP), intermediate mesoderm (IM), neural tube (NT) and notochord (NtC). Color coding of dermomyotome (red), sclerotome (yellow) and lateral plate (green) corresponds to tissues in later stage embryo in (C).

(C) Schematic cross section through a thoracic level at approximately stage 24. Sclerotome (yellow) has separated from dermomyotome (red) and the ventral edge of dermomyotome crosses the dorsal somitic frontier (arrow) into the lateral plate mesoderm (green).

Analysis of skeletal musculature of this group of embryos shows some common muscle defects. Figure 3D shows a ventral view of a 23/24 So host embryo that received a graft from a 9 So donor. When compared with the contralateral side (right), the operated side (left) of the embryo shows a number of dorsal muscle defects at the graft site (Fig. 3D). The affected specimens show normal cervical type muscle morphology at the thoracic level graft site for muscles in the dorsal compartment. The musculature of the ventral body wall on the operated side appears slightly distorted, but all four ventrolateral abdominal muscles can be identified by their relative positions and fiber orientations. Sections stained with QCPN reveal quail cells mixed with chick cells in these muscles in 7-day-old chicks (data not shown). Thus, the cervical tissue behaves autonomously in the dorsal compartment, but is able to incorporate into ventral compartment structures.

\section{P-to-A transplants}

A total of 20 embryos with transplants of SP from the level of So 19-24 to the level of So 9-14, were allowed to develop for 7 days. Skeletal preparations were performed on 18 of these embryos and muscle analysis was performed on two embryos as listed in Table 1. The specimens in Fig. 3F-J illustrate the most common disruptions produced by this type of surgery. Defects of the skeleton and musculature are again limited to the operated side of the embryo and occur at the level of the graft site.

Skeletal abnormalities include several ectopic ribs (Fig. 3F) at the cervical level, changes in vertebral shape (Fig. 3F,G), and scapular defects. No limb defects were observed. As seen in dorsal whole-mount view (Fig. 3F), the area of the graft site has more thoracic-type skeletal morphology than cervical morphology. Thus, the skeletal derivatives have maintained thoracic identity

Analysis of skeletal muscles shows that hosts that have received thoracic-level grafts at cervical levels also show differences in dorsal compartment muscle patterning on the operated side (left) when compared with the contralateral control side (right). Fig. 3I,J shows ventral views of an embryo that has received SP from the thoracic (So 20) level into the cervical level (So 12-15). At the graft site, dorsal compartment musculature displays thoracic morphology at the cervical level. The pectoralis muscle is normal on the operated side, as are the intrinsic limb muscles that normally arise from somites 1220. Again, it appears that dorsal compartment musculature maintains a thoracic pattern.

\section{Results of whole-mount in situ hybridizations on transplant embryos}

Expression patterns 48-72 hours after surgery are shown by in situ hybridization. Left, unoperated sides of all embryos show the normal expression patterns. Numbers of surgeries performed and analyzed are summarized in Table 1.

\section{A-to-P transplants}

The normal anterior boundary of Hox $a 6$ falls at somite 15 in the paraxial mesoderm (Fig. 4A). On the operated side (Fig. 4B), where SP from donor So 8 level was placed at the So 21 level, there is a gap of approximately three somites worth of tissue in which Hox a6 labeling is absent from the paraxial mesoderm. Expression still appears to be normal in the flank mesoderm.

The anterior expression boundary of Hox c6 in the paraxial mesoderm lies at the level of the caudal border of the forelimb at So 19-20 (Fig. 4C). Fig. 4D shows Hox c6 expression on the right, operated side of this specimen where donor SP was taken 
Fig. 2. Summary of surgeries performed. Blocks of segmental plate were grafted both from A-to-P and P-to-A, around morphological boundaries. The Hox genes examined are based on the normal expression boundaries that coincide with these morphological boundaries.

\begin{tabular}{|c|c|c|c|c|}
\hline \multicolumn{5}{|c|}{ Anterior to Posterior Transplant Summary } \\
\hline Stage & Donor 10 & Host 12 & Donor 11 & Host 13 \\
\hline $\begin{array}{l}\text { Somite } \\
\text { Equivalent }\end{array}$ & $9-14$ & 19-24 & $12-16$ & $20-26$ \\
\hline Surgeries & $\begin{array}{r}9 \\
\text { 影总 } \\
108 \\
0\end{array}$ & 跑 & \begin{tabular}{r|r}
8 \\
8 \\
8 \\
8 \\
8
\end{tabular} & 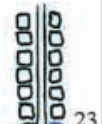 \\
\hline & $\begin{array}{l}\text { Donor } \\
\text { Stage } 10\end{array}$ & $\begin{array}{l}\text { Host } \\
\text { Stage } 12\end{array}$ & $\begin{array}{l}\text { Donor } \\
\text { Stage } 11 \\
\end{array}$ & $\begin{array}{l}\text { Host } \\
\text { Stage } 13 \\
\end{array}$ \\
\hline $\begin{array}{l}\text { Test host } \\
\text { For }\end{array}$ & $\begin{array}{l}\text { Hox a6 } \\
\text { Hox c6 }\end{array}$ & & $\begin{array}{l}\text { Hox c8 } \\
\text { Hox c9 }\end{array}$ & \\
\hline
\end{tabular}

\begin{tabular}{|c|c|c|c|c|}
\hline \multicolumn{5}{|c|}{ Posterior to Anterior Transplant Summary } \\
\hline Stage & Donor 12 & Host 10 & Donor 13 & Host 11 \\
\hline $\begin{array}{l}\text { Somite } \\
\text { Equivalent }\end{array}$ & $19-24$ & 9-14 & $20-26$ & $12-16$ \\
\hline Surgeries & 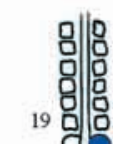 & $\begin{array}{l}0.08 \\
0 \\
0 \\
8 \\
0 \\
0 \\
0\end{array}$ & 㓢| & $\begin{array}{l}8 \\
8 \\
8 \\
8 \\
0\end{array}$ \\
\hline & $\begin{array}{l}\text { Donor } \\
\text { Stage } 1\end{array}$ & $\begin{array}{l}\text { Host } \\
\text { Stage } 10\end{array}$ & $\begin{array}{l}\text { Donor } \\
\text { Stage } 13\end{array}$ & $\begin{array}{l}\text { Host } \\
\text { Stage } 11\end{array}$ \\
\hline $\begin{array}{l}\text { Test host } \\
\text { For }\end{array}$ & $\begin{array}{l}\text { Hox a } \\
\text { Hox c }\end{array}$ & & $\begin{array}{l}\text { Hox c8 } \\
\text { Hox c9 }\end{array}$ & \\
\hline
\end{tabular}

from the So 13 level, and placed at the host So 23 level. On the operated side (Fig. 4D), there is a gap in Hox c6 labeling in the paraxial mesoderm for the length of approximately three somites, at the presumed graft site. In this embryo, the expression of Hox c 6 appears reduced in the flank at the edge of the somites but sections of the specimen show flank expression is intact (data not shown). Neural tube labeling also remained.
Fig. 4E shows the normal somitic expression boundary of Hox $c 8$ at So 22. On the contralateral, operated side, SP from So level 16/17 was grafted to So level 25/26. Again, an absence of expression of Hox $c 8$ at the presumptive graft site produces a gap in labeling for a length of approx. three to four somites (Fig. 4F). Thus, grafted tissues do not upregulate the Hox gene of interest at the new axial position.

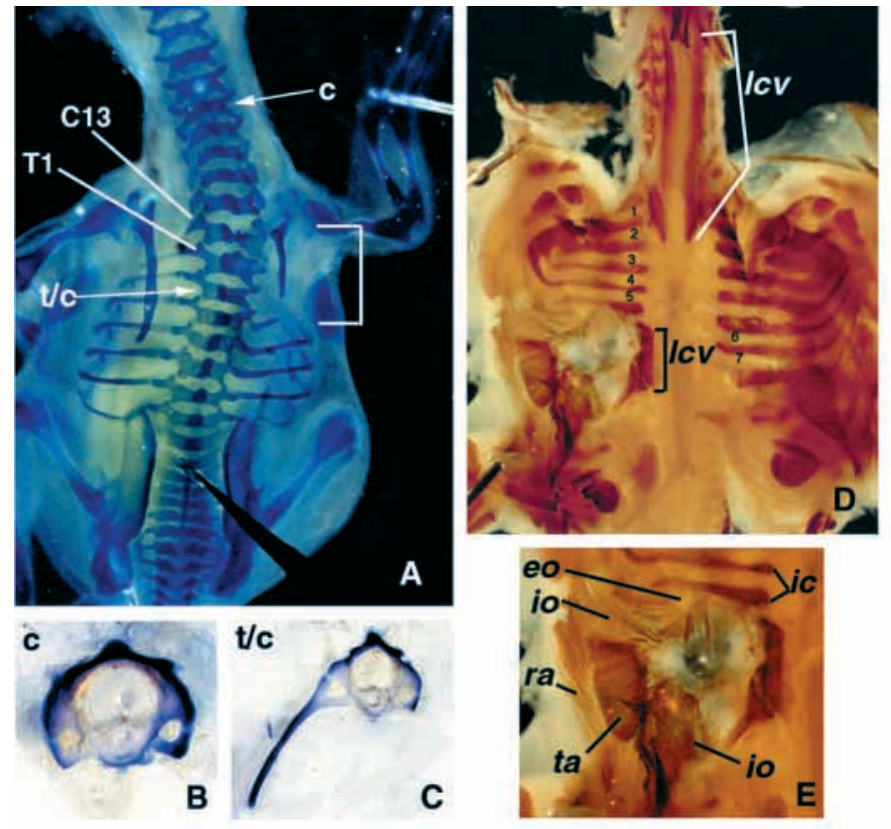

Anterior to Posterior
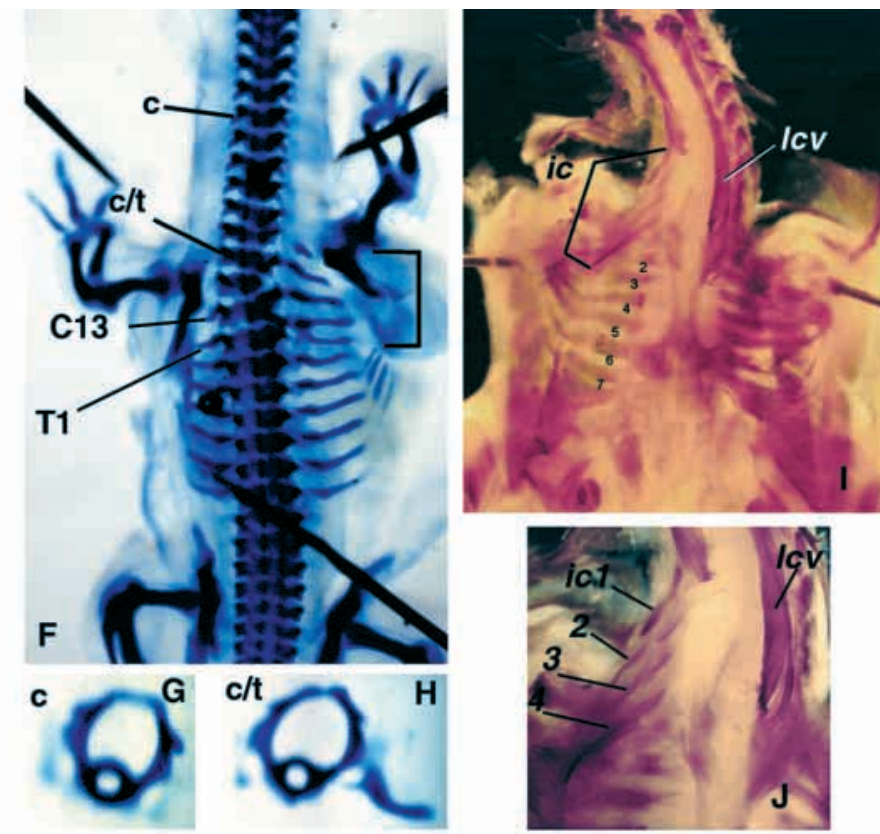

Posterior to Anterior

Fig. 3. Analysis of skeletal (A-C,F-H) and muscular (D,E,I,J) patterns in transplant embryos. (A) Dorsal view of A-to-P transplant shows skeletal defects on the operated side (right). Several ribs are missing at the transplant site (bracket) and half the vertebrae are shaped more like cervical (c) than thoracic (t) vertebrae (compare the cervical vertebra in B with the chimeric vertebra (t/c) in C). (D,E) Ventral view of A-to-P transplant shows missing thoracic intercostal muscles (ic) (6-7) and ectopic cervical m. longus colli ventralis (lcv) on the operated (left) side (black bracket; compare with $l c v$, white bracket). All layers of ventral abdominal muscle are intact at the surgery site (E), including external (eo) and internal obliques (io), and rectus ( $\mathrm{ra}$ ) and transverse $(\mathrm{ta})$ abdominus. (F) Dorsal view of P-to-A transplant shows axial skeletal defects on operated (right) side, including ectopic ribs (bracket). Dissected vertebrae show that the operated side of a chimeric vertebra (c/t) resembles thoracic $(\mathrm{H}$, right) not cervical (c) type vertebrae $(\mathrm{G})$. (I,J) Ventral views of P-to-A transplant show ectopic intercostal (ic) muscles (bracket in I, 1-4 in J) on operated side (left) and lack of cervical muscle m. longus colli ventralis $(l c v)$ at the graft site. (J) is a higher magnification of (I). 

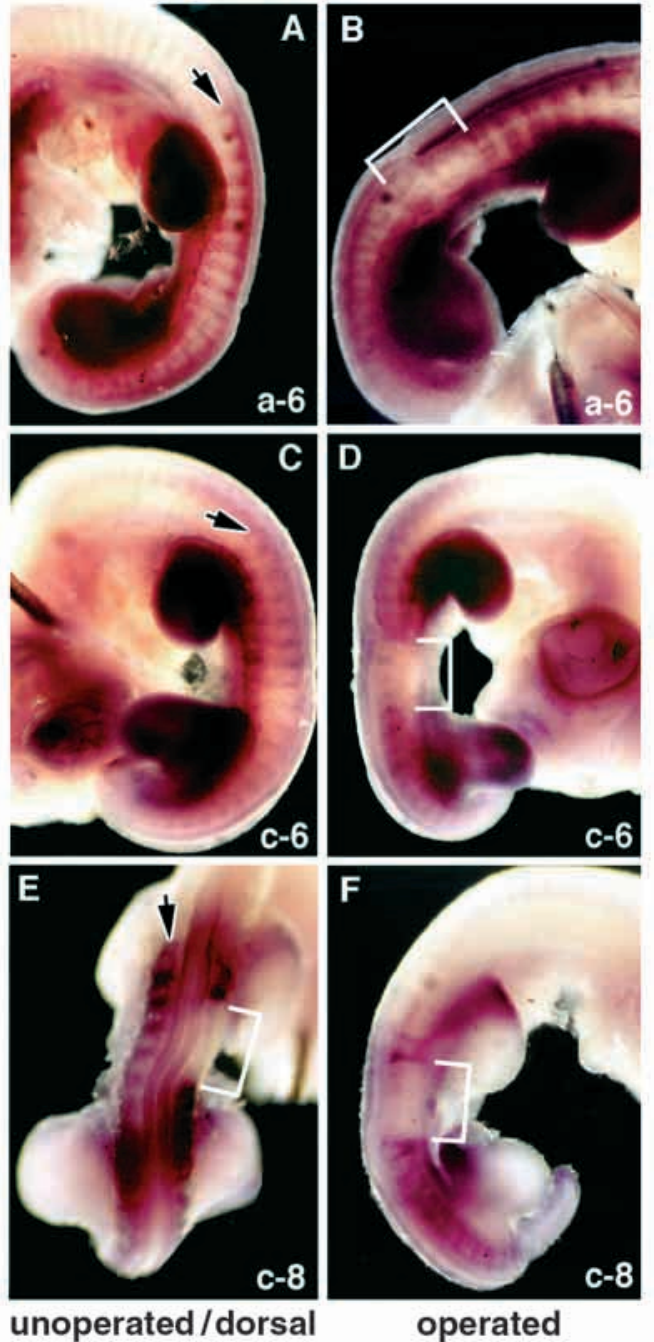

Fig. 4. Hox expression in A-to-P transplant embryos at stage 23/24. Arrows indicate anterior boundaries of expression in somitic mesoderm. Left panels (A,C,E) show unoperated, normal side in lateral $(\mathrm{A}, \mathrm{C})$ or dorsal $(\mathrm{E})$ views. Right panels $(\mathrm{B}, \mathrm{D}, \mathrm{F})$ show operated side lateral views. In each panel on the operated side, there is a lack of expression of the Hox gene assayed (Hox a6 (A,B), Hox $c 6(\mathrm{C}, \mathrm{D}), \operatorname{Hox} c 8(\mathrm{E}, \mathrm{F}))$ at the presumptive graft site (brackets).

\section{P-to-A transplants}

Fig. 5A-C shows an embryo in which donor SP from So level 21 was placed at the host So 12 level. Normal expression is seen on the left, unoperated side (Fig. 5A,C) with the anterior Hox $a 6$ boundary at the So 14 level. On the right, operated side (Fig. 5B,C) expression of Hox a6 is seen in the paraxial mesoderm at the graft site, approximately two to three somites anterior to the normal expression boundary. The offset of boundaries on either side of the embryo is seen clearly in dorsal view (Fig. 5C). Labeling in the cervical lateral plate and neural tube appear normal.

In Fig. 5D the normal expression boundary of Hox c6 at So 19 is seen on the left, unoperated side. On the right, operated side (Fig. 5E) donor SP from the level of So 21 was placed at the level of So 13. The expression of Hox c6 is seen beyond its normal anterior boundary (arrow in Fig. 5E). Labeling

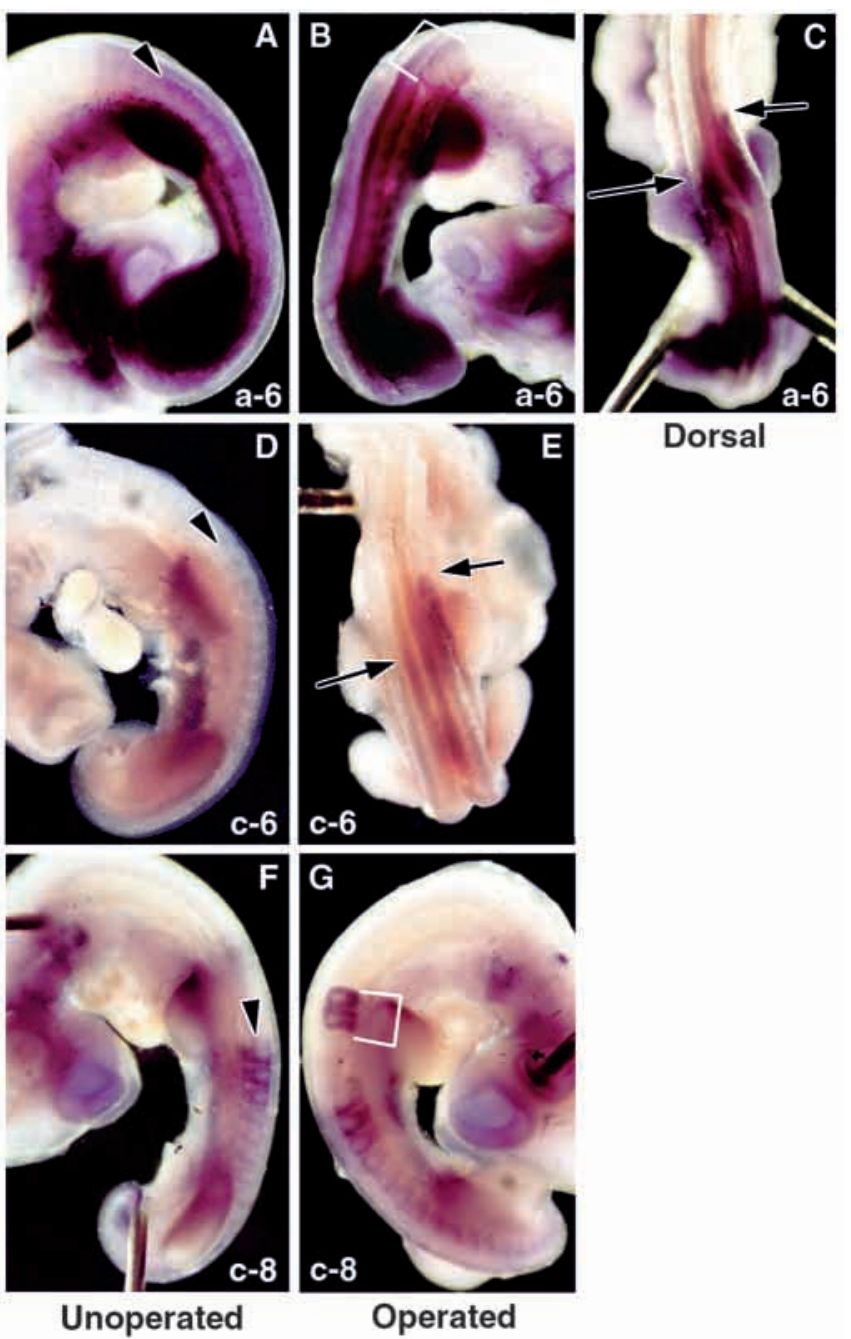

Fig. 5. Hox expression in P-to-A transplant embryos at stage 23/24. Left panels $(\mathrm{A}, \mathrm{D}, \mathrm{F})$ show normal unoperated sides of embryos in lateral view; arrowheads in these panels represent normal expression boundaries. (B,G) show lateral views of right, operated sides, and $(\mathrm{C}, \mathrm{E})$ show dorsal views of operated embryos. (B,E) Anterior shifts in expression boundaries occur for Hox a6 (bracket in B) and Hox c6 (compare arrows in E) at the graft level. Hox $c 8$ expression on the operated side $(\mathrm{G})$ shows two somites worth of ectopic expression at the graft site (bracket), cranial to the normal anterior expression boundary $(\mathrm{F})$.

appears in two to three additional somites worth of paraxial mesoderm, up to the anterior edge of the forelimb bud. This offset in anterior boundaries can be seen clearly in dorsal view (Fig. 5E).

Fig. 5F, shows the unoperated side of an embryo with So 21 level SP placed at the So 14 level. The normal boundary of Hox $c 8$ expression lies at So 22. On the operated side (Fig. 5G), Hox $c 8$ is observed abnormally labeling two somites (So 15 and 16) that lie four somites above the normal expression boundary of Hox $c 8$ in the thorax. Although these somites lie at forelimb level, the expression of Hox $c 8$ in the forelimb mesoderm appears normal, as does neural tube expression.

Similar analysis was performed on embryos with similar 


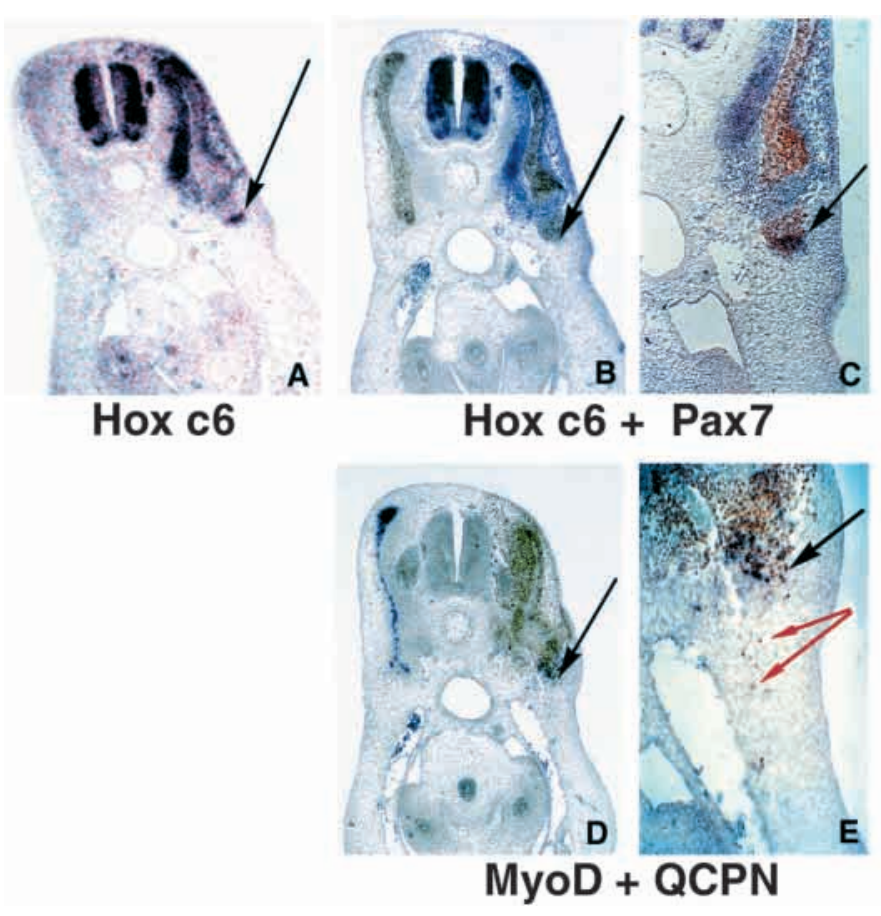

Fig. 6. Hox and muscle markers in thoracic to cervical transplants. Alternating sections of stage 23/24 embryo, through the level of the graft, stained for Hox c6 (purple in A-C), or MyoD (purple in D,E,) by in situ hybridization. Pax7 (brown in B,C) and QCPN (brown in $\mathrm{D}, \mathrm{E})$ antibody stains were subsequently performed on these sections. (A-C) Ectopic Hox c6 expression on the operated (right) side is seen in the dorsal somitic tissue that corresponds to the donor cells in $(\mathrm{D}, \mathrm{E})$. This expression is seen only up to the somitic frontier (black arrow in A-C). Although a few, scattered donor cells cross the somitic frontier into LP (red arrows in E), no cells expressing Hox c6 are found in the $\mathrm{LP}(\mathrm{C}) \cdot \operatorname{Pax} 7(\mathrm{~B}, \mathrm{C})$ and $M y o D(\mathrm{D}, \mathrm{E})$ are relatively normal on the operated (right) sides as compared with unoperated sides.

surgeries using the Hox $c 9$ probe. Hox $c 9$ was observed on the operated side above its normal anterior boundary of expression (data not shown). Thus, grafted tissues do not downregulate the Hox gene of interest at the graft site.

\section{Examination of Hox expression in somitic cell populations}

To examine Hox expression in dorsal and ventral compartments, we labeled alternating sections of surgical specimens for Hox expression and several somitic markers $(n=16)$. To observe migratory and determined muscle precursors, we used Pax3, Pax7 and MyoD. To observe graft cells, we used QCPN quail-specific antibody. Antibody staining was carried out after in situ hybridization.

P-to-A

Fig. 6 shows results of transplants of donor SP from the level of So 25 (thoracic region) to the cervical level (So 11). The left sides of the sections show the normal pattern of expression of Pax7, MyoD and Hox c6. Normal expression of Hox c6 (purple) in the neck appears only in the neural tissues (Fig. 6A,B). The expression of $M y o D$ (purple in Fig. 6D,E) and Pax7 (brown in 6B,C) at the cervical level is limited to the dorsal compartment and is absent from the cervical lateral plate (Fig. 6B-E).

On the operated side, graft cells are observed throughout the sclerotome and dorsal dermomyotome of the host up to the somitic frontier (Fig. 6D). However, few graft cells are apparent in the lateral plate of the host tissue (Fig. 6E). Both muscle markers, MyoD (Fig. 6D,E) and Pax7 (Fig. 6B,C), appear relatively normal, but slightly expanded in comparison to the unoperated side. Hox $c 6$ is expressed throughout the somitic tissue (Fig. 6A,B). No Hox c6 expression is seen in the lateral plate. Cells that express Hox $c 6$ are identified as host cells after QCPN staining (brown in Fig. 6D,E). Hox a6 shows a similar distribution in both normal and operated specimens (data not shown).

In addition to thoracic-to-cervical level transplants, thoracic to brachial transplants were performed. Left sides of the sections in Fig. 7 show the normal expression patterns of Hox $c 8$ (purple in Fig. 7A-C) and Pax3 (purple in Fig. 7D-F) at the brachial level. Hox $c 8$ expression is in the neural tube and distal portion of the forelimb mesenchyme, but not in the dorsal somitic tissues (Fig. 7A-C). Pax3 labeling reflects the highly migratory means by which the ventrolateral tissues cross the somitic frontier into the limb (Fig. 7D-F). Streams of labeled mesenchymal cells infiltrate the limb mesenchyme.

In grafts of thoracic level (So 25) SP to the brachial level (So 18), donor tissues are observed in the dorsal dermomyotome and sclerotome of the somitic mesoderm (brown in Fig. 7B,C,E,F). In addition, a stream of donor cells has crossed the somitic frontier into the lateral plate mesoderm (Fig. 7B,C,E,F). The labeling of this stream of donor cells overlaps the Pax3 staining of muscle precursor cells migrating into proximal limb mesenchyme (Fig. 7E,F).

In alternating sections of the same embryo, Hox $c 8$ expression is present in the sclerotome and dorsal dermomyotome of the transplanted thoracic tissue. The expression of Hox $c 8$ has a distinct boundary at the somitic frontier (black arrow in Fig. 7A). QCPN staining of the same section shows cells that cross the frontier do not express thoracic Hox $c 8$ (Fig. 7B,C). Thus, the ventral compartment somite cells do not appear to maintain thoracic Hox after crossing the frontier.

\section{A-to-P}

The left sides of the sections in Fig. 8 demonstrate the normal pattern of expression of Pax7, MyoD and Hox c6 in the trunk. The trunk-type expansion of the dermomyotome is clearly seen as $M y o D$ positive cells enter the lateral plate as a continuous population (purple in Fig. 8D,E). Pax7 has a similar expression domain (brown in Fig. 8B). Hox c6 expression (purple) is strong in all somitic compartments (except myotome) as well as the lateral plate (Fig. 8A).

The right side of the sections show the results of the cervical (So 14) to thoracic (So 21/22) transplant. Quail cells (brown) are observed on this side in the dorsal tissues of the somite including sclerotome and dorsal dermomyotome (Fig. $8 \mathrm{E}, \mathrm{F})$. A clear boundary of quail somitic cells represents the somitic frontier (black arrow in Fig. 8E,F). MyoD expression is reduced in the dorsal somite (Fig. 8D) and only a small cluster of cells is seen staining for $M y o D$ in the lateral plate 
Fig. 7. Hox and muscle markers in thoracic to brachial transplants. Alternating sections of stage $23 / 24$ embryo at the level of the graft, stained for Hox c8 (purple in A-C) or Pax3 (purple in D-F) by in situ hybridization. QCPN staining (brown in A-F) was subsequently performed on these sections. (A-C) Ectopic Hox c 8 expression is seen in the somitic mesoderm on the operated side (right) of the embryo as compared with the unoperated side (left). Expression is limited to the dorsal compartment of somitic cells and does not cross the somitic frontier (black arrows). Hox $c 8$ expression overlaps with the QCPN expression (brown in A-C,E,F) in the dorsal compartment. Donor cells migrate into the proximal forelimb mesenchyme (red arrows) past the somitic frontier. These ventral cells do not express Hox $c 8$, nor does the proximal limb mesenchyme. The migrating donor cells (red arrows) overlap with muscle precursor Pax3 expression of the ventrolateral migratory somite population.

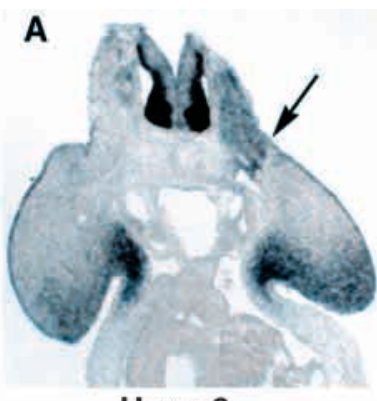

Hox c8

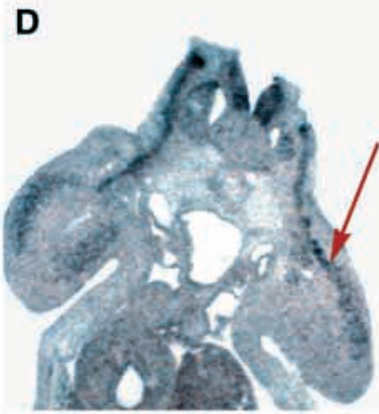

Pax3

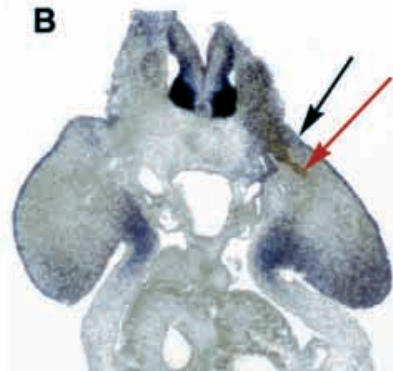

Hox c8 + QCPN

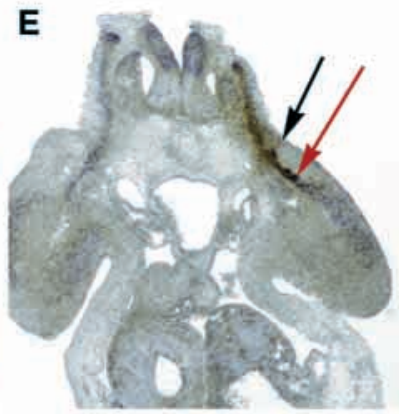

Pax3+QCPN

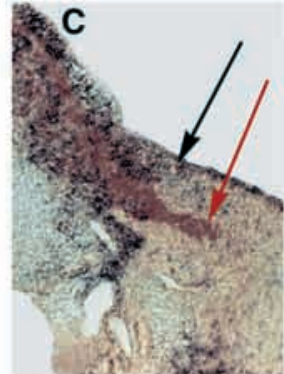

Hox c8 + QCPN

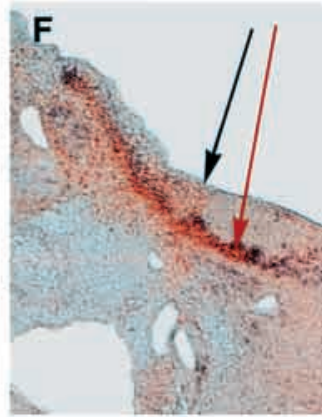

Pax3 + QCPN
(Fig. 8D). Immediately distal to the somitic frontier is a region of lateral plate tissue free of donor cells. Further laterally in the body wall a cluster of donor cells is observed that have crossed the somitic frontier (red arrow in Fig. 8E,F). Pax7 staining in the dorsal somite is normal (Fig. 8B,C). Again, a cluster of cells stain for $\operatorname{Pax} 7$ in the lateral plate, which correspond to the donor cells in the subsequent section (Fig. 8B,C).
Hox c6 expression is absent from the sclerotome and dermomyotome of the dorsal somitic mesoderm on the operated side (Fig. 8A,B). However, the cluster of cells in the body wall that is positive for $M y o D, \operatorname{Pax} 7$ and QCPN also expresses Hoxc6 (red arrow in Fig. 8B,C). Thus it appears that some cervical donor cells are able to enter the ventral compartment of the thoracic body wall and express Hox genes of a new axial level.
Fig. 8. Analysis of Hox and muscle markers in cervical to thoracic transplants. Alternating sections of stage 23/24 embryo, at the level of the graft, stained for Hox c6 (purple in A-C) or MyoD (purple in D-G) by in situ hybridization. Pax7 or QCPN antibody stains, were subsequently performed on these sections. B,C and E,F are higher magnifications of A and D, respectively. (A-C) Hox c6 expression is absent from the dorsal compartment somitic mesoderm on the operated side (right) as compared with the unoperated (left) side. Hox c6 is expressed in the LP tissue, including a cluster of cells on the ventral body wall (red arrows in A-C). Donor cells are present in the dorsal somitic compartment (brown in D-G) up to a sharp boundary at the somitic frontier (black arrows). Additional donor cells are observed in a cluster of cells in the ventral LP (red arrows in D-F and at higher magnification in $\mathrm{G}$ ), which corresponds to Hox c6 expressing cells in an equivalent section (red arrow in A-C). Pax7 and $M y o D$ expression are relatively normal in the dorsal compartment (A,B,D,E). In the lateral plate mesoderm, both Pax7 and $M y o D$ are seen in a cluster of cells that corresponds with Hox c6-expressing cells and QCPN-labeled donor cells (red arrows in A-F).
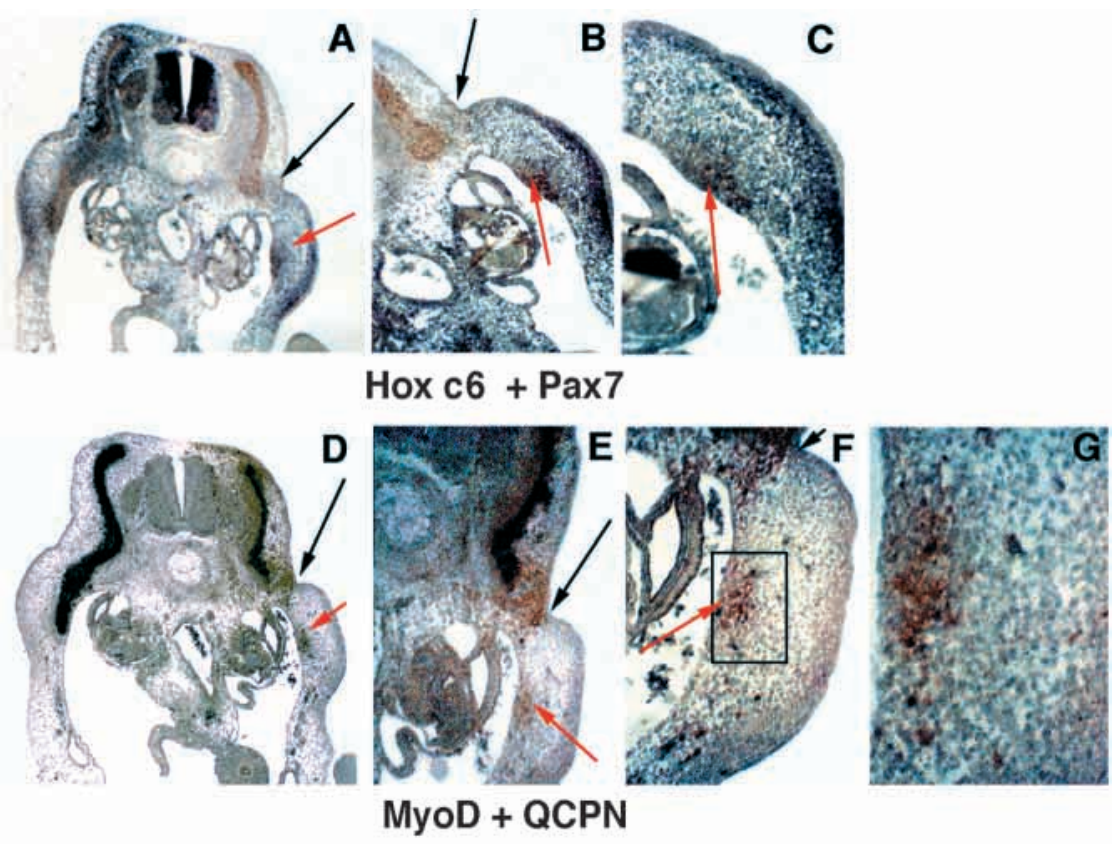


\section{DISCUSSION}

\section{Patterning of somite derivatives Dorsal compartment}

Our experiments confirm the existence of autonomous patterning in the dorsal compartment in agreement with the skeletal results of Kieny et al. (1972). In addition, our data includes examination of muscle patterning and supports data of Murakami and Nakamura (1991), specifically, the dorsal compartment of the dermomyotome maintains the muscle morphology specific to its site of origin.

\section{Ventral compartment}

From their experiments, Murakami and Nakamura (1991) conclude that somite cells are committed to form level specific muscles prior to transplantation. This is in contrast to results reported by others. Extensive transplants indicate that the muscles that form in the ventral compartment are patterned by the lateral plate in which they differentiate (Chevallier et al., 1977; Chevallier, 1977, 1978). Our data agree with the latter studies.

To determine the behavior of somitic cells in the ventral compartment, we observed the contribution of donor cells to various muscle groups. In hosts receiving grafts of thoracic somites at the cervical level, ectopic ventral muscle did not form in the cervical lateral plate (Fig. 3I) and only a few cells can be found crossing the somitic frontier (Fig. 6). Two interpretations could explain this behavior. It is possible that the lateral plate in the neck is unable to support expansion of ventral somitic tissue, preventing migration. Conversely, the donor somite cells in the ventral compartment may be respecified to a cervical identity when they cross the somitic frontier. Our experiments do not allow discrimination between these possibilities, but we hypothesize that the cells have been respecified to a cervical fate. This hypothesis is strongly supported by examination of brachial level transplants, where the appendicular muscles make up the ventral compartment. In these cases, donor cells do cross the somitic frontier into the limb mesenchyme to contribute to forelimb and pectoral musculature.

In our transplants of cervical somites to the thoracic/lumbar region, normal abdominal muscles are formed (Fig. 3D,E). We confirmed that donor cells contribute to these muscles. This suggests that ventral dermomyotomes from the cervical somites can cross the somitic frontier, enter the thoracic lateral plate (LP) and contribute to the ventral muscles specific to their new axial level. This expansion is apparently not as a continuous sheet of cells (Fig. 8), because there is a large gap where no muscle cells are found. We suggest that the appearance of the gap results from the failure of the grafted somites to expand to the same degree as the host thorax. As a result, the dorsolateral body wall of the thorax, the thoracic dorsal compartment, is not formed by the transplanted cervical somites. These results suggest that the ventrolateral somite cells are plastic and take on the identity of the lateral plate mesoderm into which they migrate.

\section{Hox gene expression and patterning of somite derivatives}

Our investigation concentrates on four Hox genes with expression boundaries within the thorax. At the time of the surgeries (H\&H stage 10-13), it is not possible to identify definitively the expression domains of these genes (see discussion below). At later stages, each gene shows differences in the position of an anterior expression boundary in neural, paraxial, limb and trunk lateral mesoderm.

The offset anterior boundaries of expression in mesodermal populations have been reported elsewhere. Cohn et al. (1997) and Oberg and Eichele (1999) show differences in the Hox boundaries in the somites and lateral plate tissue (see discussion below). We have examined the interface between these two cell populations under experimental conditions in order to better understand the alignment of Hox codes.

\section{Maintenance of Hox codes in surgically challenged somites}

In both types of surgery, the transplanted tissue in the dorsal compartment maintains expression of the Hox gene examined in whole mount. In A-to-P transplants, Hox expression is not upregulated to match the new site (Fig. 4), and in P-to-A transplants Hox expression is not shut down to conform to the new address (Fig. 5). This is the case for all four Hox genes examined (Hox a6, Hox c6, Hox $c 8$ and Hox c9). These data correlate well with the morphological data for sclerotomal tissues, as well as the dorsal dermomyotomal tissues.

\section{Thoracic to cervical transplants}

After transplant, the thoracic donor tissue undergoes relatively normal expansion of its dorsal compartment. The ventrolateral tissues, however, do not penetrate the lateral plate mesoderm of the neck as they normally would in the trunk. Consistent with this, thoracic dorsal somite maintains the expression of the Hox genes appropriate to the donor thoracic level (Fig. 6AC). This expression is not 'carried' across the somitic frontier into the lateral plate with ventrolateral somite cells. Again, this may be due to the fact that only a few scattered cells actually migrate into the cervical lateral plate (Fig. 6E). It appears that the dorsal compartment is able to maintain its original Hox code, whereas the ventrolateral compartment may not.

Thoracic transplants to the brachial level maintain Hox expression appropriate to the thoracic level in the dorsal compartment (Fig. 7A-C). The thoracic donor cells cross the somitic frontier and begin a migration into limb mesenchyme. The donor ventrolateral somite cells do not express the Hox gene expressed in the dorsal portion, and thus appear to take on the expression of the lateral plate (Fig. 7B,C,E,F). This supports our hypothesis that ventrolateral somite cells are plastic in terms of their Hox expression when confronted with a new axial address.

\section{Cervical to thoracic transplants}

After transplant, cervical donor tissue in the thorax does not expand to the extent that the thoracic tissue normally does (Fig. 8E,F). The absence of Hox c6 expression (Fig. 8A-C) in this dorsal tissue is normal for cervical cells. Some donor cells are found in the ventral compartment. This ventrolateral group of cells does express Hox c6, as does the lateral plate mesoderm at this level. These somitic cells have apparently adopted the Hox expression of the lateral plate into which they migrate.

Our results demonstrate that while the dorsal compartment is able to maintain its original Hox code, the cells destined for the ventrolateral compartment remain plastic. Hox expression 
is, thus, consistently correlated with morphological behavior. This finding is consistent with many other types of experimental results, including classical fate mapping and many molecular perturbations. Knockout of genes involved in the myogenic pathway generally show different responses in dorsal versus ventral compartments (cf. Ordahl and Williams, 1998). The participation of the lateral plate mesoderm in structures of the ventral compartment adds a critical factor to the interpretation of experimental results. As an alternative to the assumption of distinct lineage properties within each somite, we suggest that somite cells in the dorsal and ventral compartments are subject to different regulatory networks. The lateral plate and its Hox code must be considered as a source of these influences in the ventral compartment.

\section{Implications of the correlation of morphological pattern and Hox expression}

A combinatorial 'Hox code' that patterns the AP axis was originally proposed by Kessel and Gruss (1991). Evidence that such a Hox code influences the morphological identity of vertebra continues to accumulate. The axial structures derived from the somites do not function in isolation, however, but must be patterned in such a way as to work in harmony with lateral structures. This brings into question how axial (somite) patterning is coordinated with lateral structures in the global context.

The initial events leading to the AP regionalization of the vertebrate embryonic axis probably occur during the movements of gastrulation that bring the embryonic germ layers into their phylotypic positions (Boncinelli and Mallamaci, 1995; Slack et al., 1993) (Fig. 1B). The combinatorial, co-linear Hox codes in neurectoderm, mesoderm and endoderm appear to be a result of these largely unknown regulatory events. There is some evidence that these expression domains are regulated independently in different tissues (Shashikant and Ruddle, 1996; Carr et al., 1998; Becker et al., 1996).

Several studies have demonstrated that specific Hox genes have different anterior expression borders in paraxial mesoderm and lateral plate mesoderm (Cohn et al., 1997; Oberg and Eichele, 1999). Coates and Cohn (1998) suggest that the evolution of the paired fins/limbs may have resulted from novel interactions within a lateral plate already regionalized by Hox genes under the influence of the endoderm.

While the association of the lateral plate with the endoderm seems a very plausible hypothesis for the different regulation of Hox expression in this tissue, the problem remains of how lateral structures are properly aligned with axial regions. In tetrapods, the forelimb is consistently placed at the cervicalthoracic transition and the hindlimb at the lumbosacral transition, axial positions that are associated with Hox expression boundaries. As somitic and lateral plate Hox codes are apparently different, the two codes must be coordinated to produce the proper global morphology.

Though the information required for global coordination between paraxial and lateral mesoderm remains obscure, we have shown an important patterning relationship between these populations. This situation is analogous to that proposed by Noden for the relationship of muscle to neural crest-derived connective tissue in the head and branchial arches (Noden, 1983, 1986).
We propose that if the lateral dermomyotomal population does possess any axial identity, it is overwritten by the context of the lateral plate as the ventral populations migrate across the somitic frontier. Furthermore, our data suggest that these somite cells, once in the environment of the lateral plate, are acquiring lateral plate-appropriate Hox expression. These data reinforce the significance of axial Hox codes by showing correlation between maintenance of Hox expression and morphological pattern in paraxial tissues. In addition, these data support the evidence that lateral plate can dictate lateral dermomyotomal patterning, and that this pattern may also be enforced by a Hox code.

We are grateful to the following people for probe constructs: M. Bronner-Fraser (Pax3 and MyoD), the Tabin lab (chick Hox c6, Hox $c 8$ and Hox $c 9$ ) and A. Kuroiwa (Hox a6). We thank K. Oberg and L. Jacks for access to unpublished Hox expression data, and C. Tabin, B. Goldstein, V. Bautch, S. Devoto, R. J. Cheeks and P. Hernandez for critical reading of the manuscript. We also thank $\mathrm{S}$. Whitfield for assistance with figures. This research supported by NIH R29HD35932-01 and a March of Dimes Basil O'Connor Starter Scholar Research Award to A. C. B.

\section{REFERENCES}

Becker, D., Jiang, Z., Knodler, P., Deinard, A.,Eid, R., Kidd, K., Shahikant, C., Ruddle, F. and Schughart, K. (1996). Conserved regulatory element involved in the early onset of Hoxb6 gene expression. Dev. Dyn. 205, 7381.

Beddington, R. S., Puschel, A. W. and Rashbass, P. (1992). Use of chimeras to study gene function in mesodermal tissues during gastrulation and early organogenesis. Ciba Found. Symp. 165, 61-74.

Boncinelli, E. and Mallamaci, A. (1995). Homeobox genes in vertebrate gastrulation. Curr. Opin. Genet. Dev. 5, 619-627.

Bronner-Fraser, M. (1996). Methods in avian embryology. In Methods in Cell Biology (ed. D. M. Prescott), San Diego: Academic Press.

Burke, A. C., Nelson, C. E., Morgan, B. A. and Tabin, C. J. (1995). Hox genes and the evolution of vertebrate axial morphology. Development 121, 333-346.

Burke, A. C. and Nelson, C. E. (1996). Evolutionary transposition and the vertebrate Hox genes: comparing morphology to gene expression boundaries with in situ hybridization. In Molecular Zoology, (ed. J. D. Ferraris and S. R. Palumbi), pp. 283-295, New York: Wiley-Liss.

Burke, A. C. (2000). Hox genes and the global patterning of the somitic mesoderm. Curr. Top. Dev. Biol. 47, 199-225.

Carr, J. L., Shashikant, C. S., Bailey, W. J. and Ruddle, F. H. (1998). Molecular evolution of Hox gene regulation: cloning and analysis of the lamprey hoxQ8 gene. J. Exp. Zool. 280, 73-85.

Charité, J., de Graff, W., Shen, S. and Deschamps, J. (1994). Ectopic expression of Hoxb- 8 causes duplication of the ZPA in the forelimb and homeotic transformation of axial structures. Cell 78, 589-601.

Chevallier, A. (1977). Origine des ceintures scapulaires et pelviennes chez l'embryon d'oiseau. J. Embryol. Exp. Morphol. 42, 275-292.

Chevallier, A. Kieny, M. and Mauger, A. (1977). Limb-somite relationship: origin of the limb musculature. J. Embryol. Exp. Morphol. 41, 245-258.

Chevallier, A. (1978). Etude de la migration des cellules somitiques dans le mesoderme somatopleural de l'ebauch de l'aile. Roux's Arch. 184, 5773.

Christ, B., Jacob, M. and Jacob, H. J. (1983). On the origin and development of the ventrolateral abdominal muscles in the avian embryo. Anat. Embryol. 166, 87-101.

Coates, M. and Cohn, M. (1998). Fins, limbs, and tails: outgrowths and axial patterning in vertebrate evolution. BioEssays 20, 371-381.

Cohn, M. J., Patel, K., Krumlauf, R., Wilkinson, D. G., Clarke, J. D. W. and Tickle, C. (1997). Hox9 genes and vertebrate limb specification. Nature 387, 97-101.

Crawford, M. (1995). Transformations in null mutants of Hox genes: do they represent intercalary regenerates? BioEssays 17, 1065-1073.

Dietrich, S., Schubert, F. R., Healy, C., Sharpe, P. T. and Lumsden, A. 
(1998). Specification of the hypaxial musculature. Development 125, 22352249.

Dietrich, S. (1999). Regulation of hypaxial muscle development. Cell Tissue Res. 296, 175-182.

Duboule, D. and Dollé, P. (1989). The structural and functional organization of the murine $H O X$ gene family resembles that of Drosophila homeotic genes. EMBO J. 8, 1497-1505.

Duboule, D. (1994). Temporal colinearity and the phylotypic progression: a basis for the stability of a vertebrate bauplan and the evolution of morphologies through heterochrony. Development 120, Suppl., 135-142.

Ensini, M., Tsuchida, T. N., Belting, H.-G. and Jessell, T. M. (1998). The control of rostrocaudal pattern in the developing spinal cord: specification of motor neuron subtype identity is initiated by signals from paraxial mesoderm. Development 125, 969-982.

Gaunt, S. J. (1994). Conservation of the Hox code during morphological evolution. Int. J. Dev. Biol. 38, 549-552.

Graham, A., Papalopulu, N. and Krumlauf, R. (1989). The murine and Drosophila homeobox gene complexes have common features of organisation and expression. Cell 57, 367-378.

Gumpel-Pinot, M. (1984). Muscle and skeleton of limbs and body wall. In Chimeras in Developmental Biology, (ed. N.M. Douarin and A. MacLaren.), pp. 281-310, London: Academic Press.

Hamburger, V. and Hamilton, H. L. (1951). A series of normal stages in the development of the chick embryo. J. Morphol. 88, 49-92.

Itasaki, N., Sharpe, J., Morrison, A. and Krumlauf, R. (1996). Reprogramming Hox expression in the vertebrate hindbrain: Influence of paraxial mesoderm and rhombomere transposition. Neuron 16, 487-500.

Kant, R. and Goldstein, R. S. (1999). Plasticity of axial identity among somites: cranial somites can generate vertebrae without expressing Hox genes appropriate to the trunk. Dev. Biol. 216, 507-520.

Kardon, G. (1998). Muscle and tendon morphogenesis in the avian hind limb. Development 125, 4019-4032.

Kessel, M. and Gruss, P. (1991). Homeotic transformations of murine vertebrae and concomitant alteration of Hox codes induced by retinoic acid. Cell 76, 89-104.

Kieny, M., Mauger, A. and Sengel, P. (1972). Early regionalization of the somatic mesoderm as studied by the development of the axial skeleton of the chick embryo. Dev. Biol. 28, 142-161.

Krumlauf, R. (1992). Evolution of the vertebrate Hox homeobox genes. BioEssays 14, 245-252.

Lewis, E. B. (1978). A gene complex controling segmentation in Drosophila. Nature 276, 565-570.

Lin, Z. Y., Dechesne, C. A., Eldridge, J. and Paterson, B. M. (1989). An avian muscle factor related to $M y o D 1$ activates muscle specific promoters in nonmuscle cells of different germ layer origin and in Brd-U treated myoblasts. Genes Dev. 3, 986-996.

McGinnis, W. and Krumlauf, R. (1992). Homeobox genes and axial patterning. Cell 68, 283-302.

Murakami, G. and Nakamura, H. (1991). Somites and the pattern formation of trunk muscles: a study in quail-chick chimera. Arch. Histol. Cytol. 54, 249-258.

Nelson, C. E., Morgan, B. A., Burke, A. C., Laufer, E., DiMambro, E., Murtaugh, L. C., Gonzales, E., Tessarollo, L., Parada, L. F. and Tabin, C. J. (1996). Analysis of Hox gene expression in the chick limb bud. Development 122, 1449-1466.

Nickel, R., Schummer, A., Seiferle, E., Siller, W. G. and Wight, P. A. L. (1977). Anatomy of the Domestic Birds. New York, Heidelberg, Berlin: Springer-Verlag.

Noden, D. M. (1983). The embryonic origins of avian cephalic and cervical muscles and associative connective tissues. Am. J. Anat. 168, 257-276.

Noden, D. M. (1986). Patterning of avian craniofacial muscles. Dev. Biol. 116, 347-356.

Oberg, K. C. and Eichele, G. (1999). Hox gene expression and regulation in the presumptive wing region of the chick lateral plate mesoderm. Dev. Biol. 210, 151-180.

Ordahl, C. P. and Williams, B. A. (1998). Knowing chops from chuck: roasting MyoD redundancy. BioEssays 20, 357-362.

Rancourt, D., Teruhisa, T. and Capecchi, M. R. (1995). Genetic interaction between hoxb-5 and hoxb-6 is revealed by nonallelic noncomplementation. Genes Dev. 9, 108-122.

Romer, A. S. and Parsons, T. S. (1977). The Vertebrate Body (5th edn). Philadelphia: W.B. Saunders

Schneider, R. A. (1999). Neural crest can form cartilages normally formed during development of the avian head skeleton. Dev. Biol. 208, 441-455.

Shashikant, C. and Ruddle, F. (1996). Combinations of closely situated cis-acting elements determine tissue specific patterns and anterior extent of early Hoxc8 expression. Proc. Natl. Acad. Sci. USA 93, 1236412369.

Slack, J. M. W., Holland, P. W. H. and Graham, C. F. (1993). The zootype and the phylotypic stage. Nature 361, 490-492.

Stark, M. R., Sechrist, J., Bronner-Fraser, M. and Marcelle, C. (1997). Neural tube-ectoderm interactions are required for trigeminal placode formation. Development 124, 4287-4295.

Thery, C., Sharpe, M. J., Batley, S. J., Stern, C. D. and Gherardi, E. (1995). Expression of $H G F / S F, H G F 1 / M S P$, and $c$-met suggests new functions during early chick development. Dev. Genet. 17, 90-101. 